\title{
POIMANJE TEOLOGIJE U ERIKA PETERSONA
}

\author{
Ivica Raguž - Dino Klem
}

Sveučilište u Osijeku

Katolički bogoslovni fakultet u Đakovu

ivica.raguz@os.htnet.hr
UDK: 2Peterson,E.2-274:21Bultmann,R. 2Peterson,E.2-274:2Barth, K.

Izvorni znanstveni rad Primljeno 12/2018.

\section{Sažetak}

U radu su predstavljeni neki aspekti misli njemačkog teologa Erika Petersona o biti, preduvjetima i ulozi teologije. U prvome dijelu rada polazi se od Petersonova kritičkog stava spram dvojice suvremenika-Rudolfa Bultmanna i njegova shvaćanja teologije koja polazi od ljudske egzistencije te Karla Bartha i dijalektičke teologije. Iz Petersonove kritike dolazi se do njegova vlastitog shvaćanja teologije, pri čemu se posebno obrađuje pojam dogme, što čini drugi dio rada. Time se nastoji odrediti zašto taj pojam zauzima središnje mjesto u njegovu poimanju teologije i koje su njegove posljedice za istu.

Ključne riječi: Erik Peterson, teologija, dogma, Crkva, Karl Barth, protestantizam.

\section{UvoD}

Kršćanski govor o Bogu govor je o Bogu objave u Isusu Kristu. Stoga bi svaki pokušaj govora o Bogu kršćanske objave koji tu činjenicu ozbiljno ne uzima u obzir već na samom početku promašio svoj cilj. Tema govora o Bogu, koju ćemo u ovom radu ograničiti na upravo iznesenu pretpostavku, bit će dakle unutarnji sadržaj i polazište teologije. Na tome ćemo putu slijediti misao njemačkog teologa Erika Petersona. Cilj našeg promišljanja bit cee interpretacija Petersonova poimanja teologije, s obzirom na to da je taj autor $\mathrm{u}$ hrvatskoj teološkoj literaturi gotovo u potpunosti nezastupljen.

U prvom dijelu rada predstavit ćemo Petersonovo poimanje teologije. Ponajprije će biti riječi o kritici njegovih suvremenika Rudolfa Bultmanna i Karla Bartha jer će nas ta kritika dovesti do posebnosti Petersonove misli. Nju ćemo pokušati interpretirati oslanjajući se na temeljene pojmove koji čine srž Petersonova poimanja teologije. Pri tome će središnje mjesto zauzeti razumijevanje uvjeta i mogućnosti govora o Bogu iz perspektive kršćanstva. Tema drugog dijela rada bit 
će pojam dogme koji čini stup Petersonova poimanja teologije. Stoga će taj pojam biti potrebno dovesti u vezu s pojmovima koji su pretpostavka njegova razumijevanja, a to su Crkva, autoritet i teologija.

Svaki pokušaj interpretacije Petersonova poimanja teologije mora zastati na njegovim promišljanjima u eseju Was ist Theologie? (Što je teologija?). Taj spis nastao je prije svega kao kritika kako dijalektičke tako i egzistencijalne teologije koja je svoje najistaknutije predstavnike imala u Karlu Barthu i Rudolfu Bultmannu. Zato ćemo najprije pokušati predstaviti glavne teze te dvojice teologa, dakako, samo one koje su predmet Petersonove kritike. Nakon toga bavit ćemo se Petersonovom kritikom koja će nas odvesti do središnje teme našeg promišljanja, a to je ono bitno teologije u misaonoj perspektivi našeg autora. Petersonove teze o biti i svrsi teologije u spisu Was ist Theologie? nastale su kao reakcija na Barthove i Bultmannove postavke čvrsto usidrene u okrilju dijalektičke teologije, a sama njegova kritička reakcija vodila je $\mathrm{k}$ tome da naš autor razvije i svoje vlastito viđenje teologije. Peterson nije nikada razvio nekakav sustavan nauk o teologiji, njegova je misao fragmentarna. Stoga ćemo se pri obrađivanju tog pitanja osvrnuti tek na neke njegove teze koje pronalazimo u njegovim predavanjima koja je, još kao protestant, održao na teološkim fakultetima u Göttingenu i Bonnu između 1921. i 1929., a osobito na one koje je istaknuo u polemičnom spisu Was ist theologie? (1925.).

\section{KRITIKA GOVORA O BOGU UTEMELJENOGA U EGZISTENCIJI}

Već prvi pogled na etimološko značenje pojma teologija otkriva nam da je njegov smisao govor o Bogu. Ne ulazeći odmah u dublje analize tog pojma, zadržat ćemo se na njegovu osnovnom značenju. Naše osnovno pitanje bit će: na koji način je taj govor uopće moguće misliti? Na tom putu s ciljem dohvaćanja Petersonove misli najprije ćemo predstaviti teze evangeličkoga teologa Rudolfa Bultmanna. Polazište njegova promišljanja bila je neizmjerna distanca između Boga i čovjeka, koja pak ne može zanemariti događaj Božje objave. Stoga se Bultmann pita u kojem je horizontu moguće misliti govor o Bogu kao bitno određenje teologije. Pokušaj odgovora na taj problem Bultmann je iznio u spisu Welchen Sinn hat es, von Gott zu reden, čiji ćemo sadržaj ukratko predstaviti.

Bultmann opovrgava mogućnost govora o Bogu kao objektu ljudskog mišljenja. ${ }^{1}$ Za njega je objektivan govor o Bogu besmislica,

1 “Od Heideggera Bultmann također zadržava kritiku objektivirajućega govora te da se o Bogu ne može govoriti kao o najvišem predmetu. 'O' Bogu (über Gott) ne 
ako pod time podrazumijevamo govor u kojemu Bog postaje predmet rasprave. Svoj spis Bultmann započinje sljedećom tezom:

"Razumijemo li govor o Bogu kao govor u kojemu Bog biva njegovim objektom, onda takav govor nema nikakvog smisla, jer $\mathrm{u}$ trenutku u kojem se to događa, takav je govor izgubio svoj predmet. (...) Jer, svaki 'govor o' nečemu pretpostavlja polazište izvan onoga o čemu se govori. Polazište, pak, izvan Boga ne može postojati. Stoga se o Bogu ne može stvarno govoriti u univerzalnim iskazima i univerzalnim činjenicama bez povezanosti s konkretnom situacijom onoga koji govori."2

Budući da je Bog potpuno drugi, onaj koji determinira i obuhvaća čitavu stvarnost, pa i samog pojedinca i njegovu egzistenciju, čovjeku je nemoguće govoriti o Bogu tako da ga učini objektom svoga mišljenja i postavi se izvan njega. Štoviše, svaki ljudski govor, odnosno objektivizirajući govor o Bogu (über Gott) Bultmann smatra grijehom. No zadatak je teologije govoriti o Bogu. Čovjek, dakle, ne može nikako drugačije govoriti o Bogu, nego u nekoj formi govora za koju Bultmann smatra da je moguća samo kao Božji govor (Rede von Gott), odnosno govor iz Boga (aus Gott). Međutim, taj govor iz Boga ne može biti djelo čovjeka jer bi tada takav govor ponovno bio grijeh. Ipak, tvrdnja da je Bog potpuno drugi, prema Bultmannu, ne znači da bi čovjek trebao tražiti Boga izvan sebe samoga na način da tražeći Boga najprije mora pobjeći od samoga sebe. Bog čovjeku grješniku stoji nasuprot kao onaj koji je potpuno Drugi (Der ganz Andere). Stoga govoriti o Bogu kao potpuno Drugom, ima smisla tek onda kada čovjek uvidi da se kao čovjek nalazi u stanju grijeha u kojem on želi govoriti o Bogu, a ne može. Isto tako, želi govoriti i o svojoj egzistenciji, ali to također ne može. Ta napetost u kojoj se čovjek nalazi treba biti prihvaćena kao takva te bi o svojoj egzistenciji, tvrdi Bultmann, čovjek trebao govoriti kao onaj koji je određen Bogom, ali to može činiti samo kao grješnik, odnosno nalazeći se u situaciji u kojoj mu Bog stoji nasuprot kao potpuno drugi. ${ }^{3}$

možemo govoriti; možemo samo govoriti (iz iskustva; prev.) 'o’ Bogu (von Gott) (...) Bultmann priznaje da sve mjere opreza koje poduzima neće nikada spriječiti teologa da govori i o Bogu - zbog toga što je teologija posao grješnika.” JeanYves Lacoste, Od 19. do 20. st., u: Jean-Yves Lacoste i dr. (ur.), Povijest teologije, Kršćanska sadašnjost, Zagreb, 2013., 329.

2 Rudolf Bultmann, Welchen Sinn hat es, von Gott zu reden?, u: Isti, Glauben und verstehen. Gesammelte Aufsätze, Verlag von J. C. B. Mohr (Paul Siebeck), Tübingen, 1933., 26-37, ovdje 29.

3 Usp. Isto, 30. 
S obzirom na to da čitava stvarnost pa tako i čovjek svoju egzistenciju temelji u Bogu, Bultmann smatra da čovjek mora poći od samoga sebe, od svoje egzistencije, u nadi da će govorom o sebi moći izreći nešto i o transcendentalnom temelju svoje egzistencije o Bogu. ${ }^{4}$ Time govor o Bogu postaje govor o čovjeku:

"Ako bismo mogli govoriti o Bogu tako da govorimo iz Boga, onda bismo, isto tako, mogli govoriti o našoj egzistenciji i obratno. U svakom slučaju govor o Bogu morao bi ujedno biti, ako bi to bilo moguće, govor o nama. Stoga je ispravno sljedeće: ako se postavi pitanje kako je moguće govoriti o Bogu, odgovor mora biti: samo govoreći o nama samima." 5

Upravo to dovodi do još jednog kritičnog momenta u Bultmannovu izlaganju. Naime, ako je Bog potpuno Drugi, ne bi li čovjek koji je grješan ipak trebao šutjeti i ne govoriti o Bogu? Ako ispravno shvaćamo ideju da je Bog svemoguć i potpuno Drugi, onda nam treba biti jasno da govor o Bogu nije naša odluka, već Božja, tvrdi margburški egzeget. Jer upravo u toj dijalektičkoj napetosti u kojoj je Bog, s jedne strane, svemogući, onaj koji određuje čitavu stvarnost, a s druge strane, istodobno, potpuno Drugi spram te stvarnosti, odnosno, u kojoj je ujedno imanentan i transcendentan, Bog je taj koji čovjeka lišava bilo kakve mogućnosti odluke. ${ }^{6}$ Čovjeku je, pak, dana alternativa morati govoriti (Reden-Müssen) ili morati šutjeti (SchweigenMüssen). Stoga je jedini odgovor na pitanje možemo li i kada govoriti o Bogu - onda kada moramo! ${ }^{7}$

Time još uvijek nije sve rečeno. Ostaje pitanje, kako razumjeti to "moranje" (müssen). Bultmann drži da je, prema našem konvencionalnom načinu mišljenja, to Müssen ponovno shvaćeno objektivno, izvana, što podrazumijeva da time promatramo nas, "morajuće" (die Müssenden), kao objekt koji stoji pod uzročnom prisilom subjekta. Konkretno, to znači da Boga razumijevamo kao zapovijedajućega, odnosno kao subjekta. Drugim riječima, u tom "moranju" mi ovu određenost čovjeka Bogom vidimo kao objektivno prirodan proces. ${ }^{8}$ Međutim, Bultmann se tomu protivi jer je jedino u čemu se čovjek kao osoba ostvaruje njegova sloboda. Stoga se tom "moranju” čovjek može podložiti jedino slobodnim činom koji Bultmann shvaća kao poslušnost.

4 Usp. Thomas Ervens, Keine Theologie ohne Kirche. Eine kritische Auseinandersetzung mit Erik Peterson und Heinrich Schlier, Tyorlia-Verlag, Innsbruck - Wien, 2002., 40s.

$5 \quad$ Rudolf Bultmann, Welchen Sinn hat es, von Gott zu reden?, 33.

$6 \quad$ Usp. Thomas Ervens, Keine Theologie ohne Kirche, 41.

7 Rudolf Bultmann, Welchen Sinn hat es, von Gott zu reden?, 33.

8 Usp. Isto, 34. 
“Ovdje se 'morati' može misliti samo kao slobodan čin, jer jedino kao takav proizlazi iz našeg egzistencijalnog bitka, jedino u takvom činu mi jesmo, i to potpuno. Takav čin je poslušnost, jer poslušnost znači: podvrgnuti se moranju slobodnim činom."

Čovjek pak ne može biti siguran dolazi li to "müssen" od Boga i je li ono zbiljsko: "Za nas postoji mogućnost govorenja i djelovanja iz Boga, ako postoji kao morati. (...) Je li ovo morati zbiljsko, možemo samo vjerovati." 10

Konačno, vjera je za Bultmanna onaj istinski pračin slobode, čin u kojem se odlučujemo govoriti o Bogu ukoliko time govorimo o onome što Bog po svojoj Riječi za nas čini, a to je opravdanje. Time Bultmann tvrdi da Bog čovjeku daruje egzistenciju te mu samim time oprašta grijehe i opravdava ga, a čovjek nastavlja govoriti o Bogu svjestan da je svaki njegov pokušaj govora o Bogu grijeh, ali je istodobno svjestan da pred sobom ima samo vjeru u Božju milost koja ga može opravdati te u toj vjeri može govoriti o Bogu. ${ }^{11}$

Nakon što smo ukratko predstavili osnovne Bultmannove postavke u spisu koji je izazvao Petersonovu kritiku, sada ćemo pokušati ukazati što je predmet te kritike i što za našeg autora omogućuje teologiju te što joj je u središtu.

Peterson se snažno kritički osvrće na Bultmannove teze i, polazeći od naslova njegova spisa, pita se: tko zapravo može govoriti o Bogu? Profesor iz Göttingena drži skandaloznom Bultmannovu tvrdnju da svi trebamo govoriti o Bogu. Imajući u vidu netom spomenute Bultmannove tvrdnje, Peterson ističe tri vida govora o Bogu. $\mathrm{O}$ Bogu su, naime, govorili proroci, potom je sam Krist govorio o Bogu, a danas to čini Crkva. Peterson to u njemačkom jeziku diferencira na sljedeći način. ${ }^{12}$ Proroci govore o Bogu na način da priopćavaju Božje riječi (sagen), jer nešto se može priopćiti samo onda kada se ima što reći, a proroci su, tvrdi Peterson, trebali priopćiti Božje riječi. Taj proročki govor o Bogu (von Gott) za Petersona je posredan govor o Bogu, i to na način da njima riječ Božja dolazi od Boga te oni govore Božju riječ. Dakle, proroci, iako su govorili Božju riječ, ta riječ još uvijek nije bila otjelovljena i konačna. U tom je smislu nemoguce izjednačiti proročki i Kristov govor o Bogu. ${ }^{13}$ Krist pak ne priop-

\footnotetext{
9 Isto.

10 Isto, 35.

11 Usp. isto, 35-37.

12 Usp. Erik Peterson, Was ist Theologie?, u: Isti, Theologische Traktate, KöserVerlag, München, 1951., 22, bilješka 13.

13 Usp. isto, 22.
} 
ćava Božje riječi kao što su to činili proroci, već govori (redet) Božju Riječ jer je on sam Riječ Božja te u tom smislu neposredno govori o Bogu. Konačno, Crkva govori na način da proglašava, izriče (spricht) što u sebi nosi određeni pravni karakter. Kako ćemo vidjeti, taj se govor Crkve "oslanja” na Logosov govor o Bogu te se konkretizira u dogmi koja čovjeka konkretno pogađa i zahtijeva poslušnost u vjeri.

U kontekstu tog razlikovanja Peterson drži da jedino Kristov govor može biti smatran govorom o Bogu u punom smislu:

"Ne smijemo nikada zaboraviti jednu stvar, a to je, naime, da istinski govor o Bogu (von Gott) u punom smislu postoji samo u Krista. Samo s njim taj izričaj - govoriti o Bogu (von Gott) - ima onaj odlučujući dvosmisao, ukoliko je time izraženo da on ne govori samo nešto o Bogu (über Gott), nego, onda kada govori o Bogu (von Gott), tada je to što je rečeno o Bogu (von Gott) ujedno rečeno od Boga." 14

Dakle, samo Krist može iskustveno i subjektivno govoriti o Bogu. Istodobno, Kristov subjektivni govor o Bogu ujedno je i objektivan. Stoga je jedino Kristu koji je Logos, rođen od Boga, moguće poći od vlastite egzistencije i govoriti o Bogu "iz Boga”. U tom smislu nedopustivo bi bilo prihvatiti Bultmannovu tezu da za čovjeka postoji mogućnost govora "iz Boga", jer se time on nužno postavlja na mjesto samoga Krista. Prihvaćanjem teze da je govor o našoj egzistenciji ujedno i govor o Bogu, ukida se kvalitativna razlika između Krista, Bogočovjeka i čovjeka grješnika. Stoga svođenje teologije na subjektivnost nije i ne može biti polazište teologije.

\section{NEOZBILJNOST DIJALEKTIKE I KRITIKA KARLA BARTHA}

Za Petersona je tako iznimno važno naglasiti ovu određenost teologa objektivnim, čime se jasno protivi Bultmannovoj nakani da govor o Bogu utemelji u vlastitoj egzistenciji. Iz tog razloga Peterson ne može prihvatiti Bultmannove i Barthove tvrdnje koje teologiju svode tek na općeniti ljudski govor o Bogu u dijalektičkoj napetosti. Njihova je nakana bila učiniti teološki govor ozbiljnim. Dok Bultmann odbija mogućnost objektivirajućega govora o Bogu, Barth govor o Bogu svodi na općenito upućivanje na Boga gdje čovjek, polazeći od situacije ${ }^{15}$ u kojoj se kao čovjek nalazi, ne može reći

14 Isto.

15 "Mi trebamo kao teolozi govoriti o Bogu. Međutim, mi smo ljudi i kao takvi ne možemo govoriti o Bogu. Trebamo znati to dvoje, naše trebanje i našu 
ništa konkretno o Bogu koji ga kao potpuno Drugi nadilazi. Riječ je o dijalektičkoj napetosti između čovjekove dužnosti da govori o Bogu i njegove krajnje ograničenosti i nemogućnosti da to čini. Riječ je o dijalektici Božjega ne ljudskoj povijesti koja je povijest grijeha i Božjega opravdavajućega da izrečenoga u njegovoj objavi u Isusu Kristu. ${ }^{16}$ Stoga je Barthovo rješenje neodređenim pitanjima i odgovorima upućivati na Boga.

Iako Barth nezanemaruje Božju objavu u Isusu Kristu, Peterson primjećuje dajenedostatak Barthova pokušaja da teološki govor o Bogu učini ozbiljnim zanemarivanje konkretne prisutnosti konkretnoga Boga.

"Kakav li se napredak ovdje čini postignutim gdje nema više konkretnih pitanja, nego samo 'pitanja uopće' i gdje više ne postoji konkretan odgovor, nego samo odgovor uopće (...) Mi ne možemo reći o Bogu ništa određeno, ništa konkretno, ništa reprezentativno - to može samo sam Bog - mi samo možemo 'govoriti uopće' (...) Međutim, ozbiljnost koja proizlazi iz ove forme dijalektike, samo je prividna ozbiljnost."17

Ako ozbiljnost, kao što tvrdi francuski filozof Bruno Karsenti, pretpostavlja konkretnost, onda općenita pitanja i odgovori ne mogu upućivati na Boga jer unutar Barthove dijalektike Božja ozbiljnost ostaje tek dijalektičkom mogućnošću. ${ }^{18}$ Stoga dijalektika zbog uzimanja za ozbiljno (Ernstnehmen) dijalektičkih mogućnosti nikad ne dostiže pravu ozbiljnost. S druge strane, Bogu je vlastito to da je on konkretno prisutan. Drugim riječima, teologija zahtijeva ozbiljnost spram onoga što je konkretno i realno, a to je utjelovljenje. Utjelovljenjem se Bog na konkretan način objavio čovjeku i time omogućio relativnu mogućnost spoznatljivosti. Stoga, Božjom objavom na konkretna pitanja mogu biti dani konkretni odgovori pod uvjetom vjere iz koje proizlazi i uvjet poslušnosti:

"U vremenu između Kristova prvog i drugog dolaska isključena je ta vrsta zavođenja po mogućnosti dijalektičkoga. Po kojem zakonu? Po zakonu vjere, ukoliko je naime na mjesto svih dijalektičkih pitanja stupila vjera. Vjera, čija je bitna kvaliteta poslušnost - poslušnost koja bitno pripada vjeri tako kao što

nemogućnost, i time dati slavu Bogu.” Riječ je Barthovoj tezi objavljenoj u njegovu spisu Das Wort Gottes als die Aufgabe der Theologie koju Peterson navodi na početku svoje rasprave u Was ist Theologie?

16 Usp. Rossino Gibellini, Teologija XX. stoljeća, Kršćanska sadašnjost, Zagreb, 1999., 17-18.

17 Erik Peterson, Was ist Theologie?, 12-13.

18 Usp. Bruno Karsenti, Autorité et théologie. Peterson et la définition chrétienne du dogme, Archives de Philosophie, 74 (2011.), 149-168, ovdje 153-154. 
neposlušnost pripada biti dijalektike. Štoviše, radi se o poslušnosti koja pripada vjeri, ne kao akcident, u smislu da bi čisto teoretskom pristanku vjere posljedično bila pridodana snaga volje, također ne u smislu da bi sama vjera bila voluntativni čin, nego tako da je čin poslušnosti metafizičko-ontički podređen činu vjere, tako kao što je Eva bila metafizički podređena Adamu i kao što je Evina zavedenost podređena Adamovu padu. To je za znanje o biti kršćanske teologije od ključnoga značenja."19

Ozbiljnost se teologije dakle temelji u konkretnoj objavi i upravo to ju razlikuje od mitologije:

“Teologija se, za razliku od mita, temelji na tri pretpostavke: da postoji objava, vjera i poslušnost. Istodobno, to znači da teologija ne može postojati u formi dijalektike. Dijalektičko upućivanje na Boga vodi k neobvezujućem karakteru mitske naracije, ali ne i teologiji koja zahtijeva poslušnost. (...) Idealizam hegelijanske i barthovske spekulacije želi prihvatiti činjenicu Božjeg postajanja čovjekom kao mogućnost, kao dijalektičku mogućnost. Ali govoriti o inkarnaciji kao dijalektičkoj mogućnosti, znači u stvari ne govoriti o njoj uopće. A to je upravo ono što Barth čini."20

\section{SPECIFIČnOST TEOLOGIJE}

S obzirom na to da je ukazao kako teologija nije ni govor o Bogu, jer to pripada Kristu, ni govorenje Riječi Božje, što je vlastito prorocima, dolazimo do trećeg aspekta govora o Bogu, ključnog za Petersonovo razumijevanje teologije, a to je govor Crkve. Peterson na temelju paralelizma između Biblije i dogme nastoji argumentirati što je teologija po svojoj biti. U ovom ćemo dijelu doći do središta Petersonove misli u kojemu je teologija shvaćena kao određena dogmom.

\subsection{Teologija kao argumentacija}

Crkva svoj govor temelji na autoritetu Svetoga pisma koje kao nadahnuto pismo govori Božju riječ te, u tom smislu, predstavlja primarni autoritet. Nakon događaja uzašašća Kristova riječ ostaje u Svetom pismu te ono nastavlja govoriti Božju riječ. Međutim, Biblija, stoga što je Pismo, zapravo ne govori, tvrdi Peterson. ${ }^{21}$ Ona nije

19 Erik Peterson, Was ist Theologie?, 14-15.

20 Isto, 15-16, 17.

21 Usp. Isto, $24 \mathrm{~s}$. 
Božja Riječ, jer to je samo Logos. Biblija govori Božju riječ tek ako je izgovorena, izložena. Dok su za vrijeme Starog saveza proroci bili oni koji su izlagali Božju riječ, objavom Isusa Krista, njegovim govorom o Bogu, proročka služba Staroga saveza je prestala te su stoga potrebni novi tumači Pisma, "novozavjetni proroci", koje Peterson naziva prorocima biblijske riječi. Oni na temelju prošloga tumače Riječ, a aktualizacija te Riječi moguća je ukoliko se Pismo tumači alegorijski. ${ }^{22}$

No, danas nemamo više takve tumače - proroke biblijske riječi - već je njihovu ulogu preuzeo povjesničar koji je, prema Petersonu, sekularizirana forma novozavjetnog proroka. Sasvim logično, nameće se pitanje: je li egzegeza teologija, odnosno, možemo li reći da je takav "novozavjetni prorok" zapravo teolog? Peterson odgovara: Možemo, ali samo uvjetno, ako pretpostavimo da je egzegeza, odnosno tumačenje Pisma, samo priprava za teologiju. Prema Petersonu, starozavjetnom profetizmu koji je postojao u formi karizmatskoga navještaja odgovara novozavjetni profetizam koji se ostvaruje u duhovnom tumačenju Svetoga pisma i određenoj formi karizmatskoga homiletskog navještaja, i to u kultu. Ali, baš zato što pripada kultu nije i ne može biti teologija, već samo priprava za teologiju. Tumačenje po sebi nema snagu dogmatskog autoriteta koji obvezuje zbog toga što se u egzegezi i homiletskom navještaju ne nastavlja autoritativni Logosov govor.

"Zašto uz biblijski autoritet postoji još i dogmatski autoritet, zašto uz egzegezu postoji još i dogmatika? Zato što su egzegeza i propovijed samo nastavak starozavjetnog profetizma, ali ne i nastavak Logosova govora o Bogu. (...) Teologija ne postoji u Židova i pogana, teologija postoji samo u kršćanstvu, i to pod pretpostavkom da je utjelovljena riječ govorila o Bogu." ${ }^{23}$

Za razliku od karizmatskoga navještaja kojim se tumači ili komentira i koji nema tu mjeru konačnosti i dovršenosti, teologija nastupa s autoritetom utemeljenim u Kristovim riječima: Ja vam kažem. Bruno Karsenti, čiji nam uvidi i ovdje pomažu osvijetliti Petersonovu misao, tvrdi da se u tim Kristovim riječima nalazi korijen teologije. ${ }^{24}$ Zato će Peterson reći da "autoritet koji se očituje u teologiji jest izvedeni autoritet”. ${ }^{25}$ Ako je teologija ozbiljna, ona to jest

22 O Petersonovu zauzimanju za alegorijsko tumačenje Svetoga pisma vidi više $u$ : Erik Peterson, Allegorische Schriftaslegung (1924.), u: Isti, Ausgewählte Schriften. Theologie und Theologen, 9/1, Barbara Nichtweiss (ur.), Echter, Würzburg, 2009. (= AS 9/1), 234-243.

23 Erik Peterson, Was ist Theologie?, 26-27.

24 Usp. Bruno Karsenti, Autorité et théologie, 154.

25 Erik Peterson, Was ist Theologie?, 24. 
zato što je nositeljica dogmatskog autoriteta koji zahtijeva poslušnost. Taj je zahtjev izražen u dogmi u kojoj se objektivno i konkretno nastavlja Kristov govor: "Dogma je produžetak Kristova govora o Bogu. I zato autoritet dogme nije autoritet nekog čovjeka koji nešto zagovara ili neke ljudske sociološke konstrukcije koja nešto zagovara, nego je to Kristov autoritet koji se ovdje izriče." 66

U nastavku svoga razlaganja Peterson će zato reći da čak ni apostoli i mučenici nisu u pravom smislu teolozi, jer zadaća je apostola naviještati, a mučenika svjedočiti. Specifičnost teologije prema našemu autoru nije ni u prorokovanju, ni u egzegezi, ni u propovijedi, ni u naviještanju, ni u svjedočenju, ni u nauku. Ona svoje jedinstveno određenje ima u sljedećoj definiciji: "Teologija je nastavak činjenice da se objava Logosa utisnula u dogmu, i to takav nastavak koji se ostvaruje na način konkretne argumentacije u formama. (...) Teologija je konkretno ostvarenje toga da je Božji Logos konkretno govorio o Bogu, tako, dakle, da postoji konkretna Objava, konkretna vjera i konkretna poslušnost." 27

Ključ Petersonova razumijevanja teologije nalazi se u pojmu argumentacije. U tom pojmu na svjetlo izlazi ranije indicirana Petersonova teza da je Crkva ta koja donosi sud, ona proglašava i ovlaštena autoritetom u svom sudu donosi produžetak Kristove riječi izražene u dogmi. Time ona ne izriče tek nekakvo mišljenje, već sud koji traži poslušnost. Peterson konkretnu argumentaciju ne shvaća kao puku apologetiku, nego kao što tvrdi Karsenti: “Argumentacija je 'provedeno produženje' riječi, koje se podređuje izgovoru. Strano (joj) je pozivanje na izvanjsku subjektivnu suglasnost. To je razvoj nekog reda u kojem se odražava poslušnost." 28

Zato teolog pripada teološkom staležu jer se potpuno izručuje, stavlja se u službu Crkve, ne iznoseći vlastito mišljenje, nego, argumentirajući na predočen način, nastupa s autoritetom. Odatle je razumljivo da nije svaki religiozni govor ujedno i teologija, već samo onaj koji se podređuje dogmi. To znači da teologija nije spekulacija, nije ideja, nije tek religiozni govor koji polazi od neke opće neobvezujuće spoznaje. Takav govor Peterson naziva "teološ-

26 Isto, 30.

27 Zbog središnje važnosti te definicije donosimo citat i na njemačkome jeziku: "Die Theologie ist die in Formen konkreter Argumentation sich vollziehende Fortsetzung dessen, daß sich die Logos-Offenbarung ins Dogma hinein ausgeprägt hat. (...) Die Theologie ist der konkrete Vollzug dessen, daß der Logos Gottes konkret von Gott geredet hat, so daß es also konkrete Offenbarung, konkreten Glauben und konkreten Gehorsam gibt.” Isto, 27-28.

Bruno Karsenti, Autorité et théologie, 161. 
kim novinarstvom". ${ }^{29} \mathrm{U}$ tom smislu Peterson ističe važnost ispravnog razumijevanja Kierkegaarda za modernu teologiju. Naš autor ukazuje na pogrešnu percepciju Kierkegaardove misli, na kojeg se poziva protestantizam. ${ }^{30}$ Pogrješka je $u$ tome što protestantizam previđa činjenicu da sam Kierkegaard sebe nije smatrao teologom baš zato što je bio svjestan da govori bez autoriteta: "Kierkegaardovo djelovanje kao pisca karakteriziraju njegovi pseudonimi koji u svojoj prikrivenosti izriču upravo suprotno od otkrivenosti teološke egzistencije." ${ }^{1}$ S druge strane, teolog je svjestan da iza njega stoji autoritet Crkve i njezina nauka. S obzirom na to da u Petersonovoj misli pojam teološkoga staleža predstavlja svojevrstan uvjet mogućnosti teologije kao takve, u nastavku ćemo reći nešto više o njegovu određenju.

\subsection{Teološki stalež}

Određenost teologâ objektivnim, odnosno konkretnom objavom, iz koje teolozi crpe spoznaje te s njome daju odrediti, pretpostavlja konkretan "stalež", a to je stalež teologa. Bruno Karsenti pomaže nam uvidjeti da je kategorija staleža ono što teologa razlikuje od stanja paradoksa u kojem se nalazi dijalektičar. Dok je dijalektičar u konstantnoj napetosti između trebati-govoriti i ne-moći-govoriti, teolog pripada teološkom staležu te kao takav, postavljen od Boga i od Crkve, nastupa s autoritetom. ${ }^{32}$ Zato je teologija moguća tek u staležu, ukoliko se pod tim razumije krajnja određenost života, kierkegaardovskim rječnikom rečeno, "skok u religioznu sferu" koji se očituje kao odreknuće i realizira kao darovanost Bogu i Crkvi. Unutar te darovanosti teolog pretpostavlja autoritet koji je njemu predan od Crkve kako bi govorio, argumentirao, ne svoje misli, nego, kao što je ranije rečeno, izrečeni sud Crkve. Taj je sud izveden iz pozitivnih datosti konkretne objave utjelovljenog Logosa iskazanih u dogmi, koja zahtijeva konkretnu vjeru i konkretnu poslušnost, a time i konkretan stalež u kojem se teolog daje pogoditi dogmom, na način da ga ta dogma određuje te on svaki zemaljski autoritet podvrgava ovom autoritetu dogme.

\footnotetext{
29 Erik Peterson, Was ist Theologie?, 20.

30 O Kierkegaardovoj kritici protestantizma vidi u: Ivica Raguž, Bilješke o kršćanstvu u Dnevnicima Sørena Kierkegaarda, u: Isti, Teološki fragmenti I., Panni, Đakovo, 2016., 259-293.

31 Erik Peterson, Über die Forderung einer Theologie des Glaubens, u: Isti, AS 9/1, 303-323., 312.

32 Usp. Bruno Karsenti, Autorité et théologie, 157-158.
} 
Iz toga slijedi istinska teologija, moguća jedino unutar tog konkretnog teološkog staleža, i to zato što je tu riječ o specifično teološkom znanju. ${ }^{33}$ Naime, Peterson teologiju poima kao "prvu znanost" spram korpusa svih ostalih znanstvenih disciplina. O teologiji je, tvrdi Peterson, moguće govoriti samo u vremenu od Kristova utjelovljenja do njegova ponovnog dolaska. Do događaja Kristova uzašašća Logos je bio taj koji je s punim pravom i autoritetom govorio o Bogu. Nakon uzašašća ostaje Crkva i ostaje dogma, a time i jedinstvena zadaća teologije. Stoga je plodan teološki rad, prema Petersonu, moguć samo u Crkvi, i to u teološkom staležu unutar kojeg se teolog daje odrediti, biti konkretno pogođen dogmom. Ta se konkretnost događa "na tako opipljiv način da teolozi postoje u formi staleža, a teološka znanost u formi struke. Ipak, ne u formi neke struke, kao što su to sve ostale struke. Teologija je prva znanost. To nije rečeno iz ljudske oholosti, nego polazeći od dogme koja je podredila sve ljudsko znanje." 34

Kao što je Krist, utjelovivši se, konkretno došao u ovaj svijet i nastavlja biti prisutan u sakramentima, tako njegova riječ nastavlja biti prisutna u dogmi. Jedinstveni se karakter teologije, odnosno teološkog govora o Bogu temelji na dogmi Crkve koju ona proglašava pod pretpostavkom autoriteta kojim je Krist kao utjelovljena Riječ govorio o Bogu. Taj govor ostvaruje se kao argumentacija zbog toga što on ne polazi od osobne vjere i vlastitih (ne)mogućnosti, nego od onoga što Crkva vjeruje, a objektivno je izraženo u dogmi. Zadatak je dakle teologije argumentirati nauk Crkve izrečen u dogmi koja u sebi nosi otisak Logosova govora o Bogu. To pak znači da Objava određuje bit teologije, a ne nekakav ljudski duhovni čin kao govor, pisanje, naviještanje i sl. ${ }^{35}$ Aludirajući na naslov Bultmannova spisa, Peterson kaže: "Koliko je zadatak teologije pisati o Bogu, toliko joj je zadatak i govoriti o Bogu. Zanimljivo je za duhovnu situaciju u kojoj živimo da Barth i Bultmann govor o nečemu vrlo naivno doživljavaju kao jedinu čovjekovu religioznu i duhovnu mogućnost." 36

\subsection{Govor u teologiji}

Erik Peterson ipak nije osporio važnost govora kao forme $\mathrm{u}$ teologiji koja po svojoj etimološkoj defniciji jest teo-logija, govor o

\footnotetext{
33 Usp. Erik Peterson, Was ist Theologie?, 20-21.

34 Isto, 33-34.

35 Isto, 28.

36 Isto, 22.
} 
Bogu. O važnosti odnosa teologije spram govora Peterson je progovorio u jednoj kratkoj recenziji desetak godina nakon objavljivanja spisa Was ist Theologie?, i to u drukčijem, nepolemičnom kontekstu. Komentirajući tada novoobjavljenu dogmatiku Michaela Schmausa, Peterson je zamijetio posebnost $u$ tome što u njoj do izričaja dolazi dimenzija govornoga, odnosno navještaja, svjedočanstva: "Naprotiv, Schmausova dogmatika potrebuje govor, zato što ona u teologiji vidi ujedno i komadić svjedočanstva koji je položen za Božju riječ."37 Nadalje, Peterson će reći da je Schmausova dogmatika na određeni način "patristička", a time podrazumijeva poseban odnos prema govoru. Svojevrsna je to i kritika skolastičkoj teologiji, odnosno teologiji koja je ograničena samo na znanstvene pojmove. U Theologie und Sprache Peterson uočava kako se u patrističkim spisima uvijek može prepoznati svojevrsni govorni stil, štoviše, patristička teologija uvijek je više od znanstveno formulirane teologije, ona je uskom odnosu ne samo prema Logosu nego i prema Legein, govorenju Logosa. Peterson želi pokazati da je opravdano koristiti riječ teologija (nasuprot "teognosija"), jer se upravo u toj riječi pronalazi ono što određuje bit teologije. Teologija dakle nije teognosija, nije isključivo spoznaja, ne polazi od subjekta koji spoznaje, već polazi od govora Drugoga tako da taj primljeni govor određuje i odnos teologije prema govoru ("Theologie"). ${ }^{38}$ Stoga tvrdi naš autor: "Budući da božanska riječ u nama ne šuti, imamo teologiju, a ne puku teognosiju. Odnos prema govoru postaje nužan unutarnji kriterij za izvornost teološkoga spoznavanja uopće jer se bit teologije ne iscrpljuje ni u tvrdnjama predaje ni u formuliranju znanstvenih iskaza."39

Štoviše, teologija svoje potpuno ostvarenje u području govornoga ima onda kada sudjeluje u anđeoskoj teologiji, ${ }^{40} \mathrm{u}$ motrećoj spoznaji i proslavi Boga.

37 Erik Peterson, Theologie und Sprache, u: Isti, AS 9/1, 202-204., ovdje 202.

38 Usp. Isto, 203.

39 Isto, 204.

40 Ukazujemo također na drugi aspekt Petersonova poimanja teologije, koji nam ovdje nije moguće u cijelosti predstaviti, a riječ je o teologiji koja se ostvaruje u mističnoj spoznaji (gnosis), koja prerasta u veličanje, pohvalu i proslavu Boga. U tom kontekstu naš autor ukazuje na posebnu ulogu anđela unutar kozmičkoga reda te njihovu korespondenciju s Crkvom na zemaljskom hodočašću prema vječnoj domovini. Naime, pjesmu anđela pred licem Božjim (“Svet, svet, svet”) Peterson tumači kao čin štovanja Boga u kojem anđeli na mističan način svečano proglašavaju teologiju, odnosno pohvalu Boga. Peterson također ukazuje na dvoznačnost pojma teologija kako u antici tako i u kršćanskoj mistici. U antičkoj filozofiji theologia znači spoznaja najviših principa bića ili uzvišeni poetski govor pjesnika. U kršćanskoj mistici theologia, s jedne strane, predstavlja najvišu formu spoznaje koja svoje dovršenje ima u spoznaji Presvetog Trojstva, dok, s druge strane, 


\section{Dogma KaO POLAZIŠTE TEOLOGiJe}

Petersonovo inzistiranje na dogmi nužno je promatrati unutar odnosa objave, Crkve i dogme, iz čega u konačnici i proizlazi specifična uloga teologije. Stoga ćemo u nastavku najprije reći nešto više o autoritetu kojim Crkva može donositi dogme, a zatim i o posljedicama koje to oblikovanje dogmi ima na teologiju. Petersonovo poimanje dogme gotovo je neodvojivo od njegove kritike protestantske teologije kojoj je za vrijeme svojega profesorskog rada u Göttingenu i Bonnu i sam pripadao, dok je, s druge strane, često pokazivao tendencioznost prema nauku Katoličke Crkve, osobito u pitanjima ekleziologije i povijesti dogmi. Time smo došli do pojma koji određuje Petersonovo poimanje teologije, a to je pojam dogme. Zato ćemo u daljnjem razlaganju pokušati predstaviti središnjost značenja dogme za teologiju.

\subsection{Vlastitost i autoritet Crkve}

Prije nego predstavimo Petersonovo razumijevanje dogme, ne možemo zaobići njegovo poimanje Crkve jer su te stvarnosti jedna s drugom čvrsto povezane. Ekleziologija u Petersonovoj misli zauzima veoma važno mjesto, a za šire razlaganje njegova razumijevanja Crkve bilo bi potrebno razraditi poseban prilog. Stoga nam ovdje nije nakana ulaziti u detaljniju interpretaciju i analizu onoga što Peterson razumijeva pod pojmom Crkva, nego ćemo istaknuti nekoliko važnih teza za našu temu. ${ }^{41}$

Za prethodno razumijevanje onoga što Crkva predstavlja u Petersonovoj misli, potrebno je istaknuti Petersonovu tezu s obzi-

ta riječ upućuje na mističnu spoznaju koja zapravo nije spoznaja, već čašćenje, pohvala Boga na način čistih duhova. Tako je, tvrdi Peterson, u kršćanskoj mistici u pojmu theologia $u$ konačnici intrinzično povezano jedno značenje s drugim te u tom smislu spoznaja svoje mistično ispunjenje ostvaruje u teologiji, što zapravo podrazumijeva da spoznaja ne ostaje spoznaja, već postaje pohvala Boga na način kako to čine anđeli. Više o tome u Erik Peterson, Von den Engeln, u: Isti, Theologische Traktate, Kösel-Verlag, München, 1951., 323-409, ovdje 371ss.

U interpretaciji ove teme okosnica će nam biti struktura koju je slijedio Thomas Ervens u svojoj doktorskoj disertaciji Keine Theologie ohne Kirche. Više o Petersonovoj ekleziologiji može se pronaći u: Erik Peterson, Die Kirche, u: Isti, Theologische Traktate, Kösel-Verlag, München, 1951.; Isti, Von den Engeln, u: Isti, Theologische Traktate, Kösel-Verlag, München, 1951.; Isti, Ekklesia. Studien zum altchristlichen Kirchenbegriff, Barbara Nichtweiß, Hans-Urlich Weidemann (ur.), Echter, Würzburg, 2010. Upućujemo i na dosad jedini znanstveni doprinos o Eriku Petersonu na hrvatskome govornom području: Ivica Raguž, Crkva imperij, nacionalna država i pluralističko društvo. Aktualnost Erika Petersona, u: Isti, Teološki fragmenti III., Panni, Đakovo, 2017., 321-333. 
rom na teologiju povijesti. Naš autor Kristov inkarnacijski moment ne shvaća samo kao izvanredan događaj u povijesti spasenja, nego je Božjom objavom u Isusu iz Nazareta kozmos ušao u novi i konačni eon, i to tako da je taj eon sam Krist. ${ }^{42}$

U događaju Kristove smrti i uskrsnuća nastupa prijelomni trenutak čitave povijesti u kojem Krist svijet izvodi iz starog eona i uvodi u novi, čime vječnost prodire u vrijeme, a Bog dolazi čovjeku u susret. Time je čitava povijest dovedena u stanje "eshatološke pripravnosti” do svog konačnog ispunjenja u eshatonu. No između eshatološkoga vremena i novoga eona postoji dijalektička napetost. Naime, novi se eon spram staroga ne smije shvatiti "kao jedna epoha koja smjenjuje drugu, kao što srednji vijek slijedi nakon antike, nego se ostvaruje $u$ eshatološkom vremenu u sakramentalnoj Kristovoj prisutnosti i izlijevanju Pneume, Duha Svetoga.”43

Njemački teolog Thomas Ervens zaključuje da je u Petersonovoj misli eshatološko vrijeme, koje je započelo Kristovim prvim dolaskom, ipak još uvijek vrijeme u povijesti koje ide svome kraju, dok je novi eon onkraj te povijesti, on je transpovijesna stvarnost. ${ }^{44}$ Unutar takvog shvaćanja povijesti Crkva je prema Petersonu predstavnica nove "javnosti” koju je Krist utemeljio. Ona je dakle konkretizacija one "eshatološke pripravnosti" i kao takva usmjerena k nebeskom Jeruzalemu, eshatološkom združivanju s javnošću nebeskoga polisa. Tako je Crkva na zemlji institucija nebeskog polisa ${ }^{45}$ koja se ostvaruje kao ekklēsía - institucija javno-pravnog karaktera koja može donositi pravne odluke. Upravo to nas dovodi do pitanja ishodišta Crkve. Peterson drži da je Crkva u potpunosti utemeljena tek u odluci Dvanaestorice u Duhu Svetome (usp. Dj 15) da krenu k poganima. Upravo se u tom činu očituje povezanost božanskoga i ljudskog autoriteta te snaga Dvanaestorice da donose odluke nakon Kristova uzašašća. ${ }^{46}$ Nakon događaja uzašašća Kristovim je opunomoćenjem apostola (usp. Lk 10, 16; Mt 16, 19) Crkvi predana učiteljska i pravna vlast djelotvorna u Duhu Svetome. Time je Crkva kao

42 Erik Peterson, Die Kirche (rukopis), III. dio, citirano prema: Barbara Nichtweiss, Erik Peterson. Neue Sicht auf Leben und Werk, Herder, Freiburg, ${ }^{2} 1994 ., 485$.

43 Kurt Anglet, Der eschatologische Vorbehalt: Eine Denkfigur Erik Petersons, 122, citirano prema Thomas Ervens, Keine Theologie ohne Kirche, 66-67.

44 Usp. Thomas Ervens, Keine Theologie ohne Kirche, 67.

45 O Petersonovu poimanju Crkve kao institucije nebeskoga polisa i političkom značenju Crkve u društvu vidi Ivica Raguž, Crkva - imperij, nacionalna država i pluralističko društvo, 321-333, posebno 321-325.

46 Thomas Ervens, Keine Theologie ohne Kriche, 79; Barbara Nichtweiss, Erik Peterson, 621. 
Kristova predstavnica na zemlji legitimirana donositi dogme. ${ }^{47}$ Tako Peterson tvrdi: "Crkveno se pravo razlikuje od svakoga svjetskoga prava po svom podrijetlu od Duha Svetoga. Stoga ne može postojati disciplinska ili dogmatska odluka Crkve koja se ne bi pozivala na Duha Svetoga." 48 Pod tim je gledištem jasno, tvrdi Peterson, "da formiranje dogmi i učiteljska vlast Crkve utemeljena u crkvenom pravu ne znače pogrješno razumijevanje Krista, već da su to legitimne tvorevine Duha Svetoga". ${ }^{49}$

Na ovome mjestu potrebno je reći nešto više o povezanosti crkvenoga prava i dogmatike. Sam pojam crkvenoga prava usko je vezan uz pojam Crkve, ali i uz pojam dogme. Postojanje crkvenoga prava jamac je postojanja apsolutnoga formalnog autoriteta koji može donijeti sud, legitimirati određeni nauk i proglasiti dogmu. Iz toga proizlazi da Crkva može donositi dogme, jer pravo zahtijeva dogmu. Dogma, pak, bez postojanja crkvenoga prava nema smisla, kao ni bez postojanja crkveno-pravne vlasti koja je tu dogmu ovlaštena donijeti. To znači da ondje gdje ne postoji apostolska sukcesija, ne postoji ni crkveno-pravna vlast. Drugim riječima, ako je Krist predao vlast apostolima, a preko apostola posredno i Crkvi, onda Crkva posjeduje samostojni pravni entitet i kao takva je ovlaštena izricati sud u Kristovo ime. Peterson to temelji u činjenici da Krist nije iznosio samo nekakav nauk, nego je posjedovao i eshatološku vlast (Amen, Ja vam kažem).

Kao što smo to pokazali ranije dogma u Crkvi kao otisak Kristove objave predstavlja produžetak autoritativnog Logosova govora o Bogu. Međutim taj se govor razlikuje od načina Kristova govora prije uzašašća, odnosno za vrijeme njegove tjelesne prisutnosti u svijetu, tvrdi naš autor. Pod pretpostavkom netom iznesenog shvaćanja crkvene pravne vlasti Crkva može zahtijevati konkretnu poslušnost, a najkonkretniji objekt poslušnosti predstavlja dogma. Autoritet dogme ne temelji se na autoritetu koji je sam Krist imao i koji je bio, već je riječ o izvedenom autoritetu koji je Krist predao Dvanaestorici, odnosno Crkvi. Kada se govor Crkve svodi na Kristov govor te posljedično, kada donosi dogme snagom svoje učiteljske vlasti, Crkva kao Tijelo Kristovo ostvaruje produžetak Kristova govora. ${ }^{50} \mathrm{U}$ tom smislu, dogma, uz sakramen-

47 Erik Peterson, Der Begriff des Dogmas, u: Isti, AS 9/1, 191-197, ovdje 195.

48 Isto, 196.

49 Isto, 197.

50 Znakovito je, tvrdi Peterson, da je $\mathrm{u}$ antičkom svijetu sam pojam dogma imao snažan obvezujući karakter u pravnom smislu. Državno-pravne odredbe nekog polisa koje je donijelo njegovo nadležno tijelo, označavane su pojmom dogma. 
te, predstavlja Božji obvezujući pravni zahtjev vjere i poslušnosti koji vrijedi nakon Kristova uzašašća. Kao što je sakrament svojevrsni produžetak Kristove tjelesne prisutnosti, tako je dogma svojevrsni produžetak njegova govora. ${ }^{51}$ Stoga Peterson zaključuje:

"'U strogo teološkom smislu dogma je od Boga objavljena istina koja je izrijekom proglašena od crkvenog učiteljstva kao predmet obavezne vjere za sve.' (...) Pojmu dogme pripada to da je predložena od Crkve kao obavljena istina i predmet vjere. Pri tom se misli na 'propositio ecclesiae' o kojem govori katolička dogmatika, što znači da dogma mora biti ustanovljena i proglašena od Crkve. 'Tko' u Katoličkoj Crkvi proglašava dogmu, jesu li to zakoniti koncili ili papa, ovdje je za pojam dogme relativno sporedno pitanje. Naprotiv, važno je da je bez postojanja učiteljske vlasti pojam dogme kao takav besmislen." ${ }^{2}$

\subsection{Deficit dogmatskog autoriteta u protestantizmu}

Prikazana skica Petersonova viđenja Crkve dovodi nas do pitanja autoriteta $\mathrm{u}$ teologiji, s posebnim naglaskom na protestantsku teologiju Petersonova vremena, kojeg je na ovom mjestu potrebno pobliže izložiti. To pitanje upućuje nas i na crkvenu dogmu o kojoj će u ovom dijelu također biti riječi. Jedna od Petersonovih često upućivanih kritika novijoj protestantskoj teologiji (novoprotestantizmu) tiče se deficita dogmatskog odlučivanja i dogmatskog sadržaja. Dogma je za protestantsku teologiju postala nebitna: "Čini mi se da je nesreća naše današnje teologije u tome što ona više nije orijentirana na dogmu i nema u njoj polazište i središte svoga znanstvenoga rada." ${ }^{33}$ No taj problem, prema Petersonu, nije nastao tek uslijed nedavnih teološko-duhovnih prijepora. Već na samom početku protestantizma Peterson uviđa tri pogrješke koje su odredile put protestantske teologije bitno određen otklonom od dogme. Naime, protestantizam je svoj odnos prema dogmi zapečatio preuzimanjem tri simbola stare Crkve (Apostolski, Nicejski i Atanazijev simbol). Time je dogma smještena duboko u prošlost. Iz toga proizla-

S druge strane, prema izvornom tekstu Lk 2, 1, naredba cara Augusta kojom nalaže popis svega svijeta izdana je kao dogma. U prvim stoljećima kršćanstva tu su riječ crkveni oci koristili pri isticanju crkvenog nauka ili pak nauka nekih heretika. Usp. Erik Peterson, Der Begriff des Dogmas, 191.

51 Usp. Erik Peterson, Was ist Theologie?, 30-31.

52 Erik Peterson, Der Begriff des Dogmas, 191, 193.

53 Erik Peterson, Über die gegenwärtige Lage der Theologie, u: Isti, AS 9/1, 58-66, ovdje 61. 
zi da nije jasno zašto bi crkveno formiranje dogmi trebalo zaključiti baš sa Athanasianumom i tako ustanoviti konačnost za vjerovanje. Nadalje, nedostatak daljnje mogućnosti donošenja dogmi uvjetovao je odumiranje već preuzetih dogmi, a izostanak crkvene pravne vlasti u protestantizmu značio je kraj mogućnosti formiranja novih dogmi. ${ }^{54}$

Peterson također ukazuje na obrat koji se u modernoj teologiji dogodio pojavkom novoprotestantizma pod utjecajem Friedricha Scheleirmachera. Novoprotestantizam umjesto autoriteta Pisma i autoriteta Crkve uvodi autoritet religijskog iskustva, odnosno samosvijesti pojedinca. ${ }^{55}$ Kršćanstvo tako postaje određeno čuvstvom, a dogmatika i božanska transcendencija podređena onome što pojedinac osjeća. Na taj način moderna će teologija udariti na koncept ortodoksije u kojem Objava, ${ }^{56}$ shvaćena kao posredovanje nadnaravnog znanja dokučivoga naravnim razumom, čini temelj dogmatike.

"U stvarnosti bi ovim odbacivanjem starog pojma objave trebao biti očišćen put za modernu metafiziku usmjerenu, prije svega, na Kanta. Prema tomu sva stvarnost (uključujući i Božju stvarnost) jest stvarnost za ljudsku svijest, a Bog na direktan način stoji čovjeku nasuprot kao svi ostali predmeti ljudske svijesti." 57

Treći problem koji Peterson u kontekstu gore iznesenoga uočava tiče se odnosa teologije i autoriteta. Peterson korijen tog problema za protestantsku teologiju vidi u ukinuću crkvene tradicije shvaćene u pogledu katoličkog poimanja tradicije kao teološkoga locija što kao posljedicu ima i zanemarivanje objektivnoga u teologiji. Razlog tomu je subjektivizacija čina vjere kao spoznajnog čina koja je zahvatila protestantizam od doba prosvjetiteljstva i pijetizma, otklonivši tako sve objektivne forme crkvenog nauka koje je protestantska ortodoksija još koliko-toliko prihvaćala. Navedene prilike dovele su do iščeznuća crkvenog autoriteta, a crkveni nauk postao je tek jedno mišljenje naspram privatnih teoloških mišljenja. Tako je teologija lišena svoje ukorijenjenosti u dogmi Crkve, a autoritet dogme preuzeo je autoritet savjesti. U evangeličkoj Crkvi dolazi do miješanja između teološkog mišljenja pojedinca i doktrine Crkve, između subjektivnoga i objektivnoga. Tako pomiješano oboje biva svedeno na istu razinu važnosti i time nosi opasnost za Crkvu i teo-

\footnotetext{
54 Usp. Erik Peterson, Der Begriff des Dogmas, 191-192.

55 Lidija Matošević, Odnos prema rimokatoličanstvu u ranim radovima Karla Bartha, Diacovensia, 26 (2018.) 1, 95-115, ovdje 98, bilješka 14.

56 Erik Peterson, Thomas von Aquin. 6. Vorlesung, u: Isti, AS 9/1, 67-190, ovdje 126.

57 Isto.
} 
logiju: "Ako se smatra da živo znanje postoji tek onda kada pojedinac ili generacija kojoj on pripada počinje spoznavati, bila bi to racionalistička predrasuda. Samo duhovna nezrelost može zanijekati da je u svakoj tradiciji trajno održano živo znanje, ili drugim riječima, da ne spoznaje samo teologija nego i Crkva, da je izvor teoloških spoznaja ne samo sud profesora, nego i sud Crkve." 58

Jasno je iz do sada izloženih teza Erika Petersona da je nemoguće govoriti o teologiji ukoliko u središtu te teologije nije dogma. Međutim, Peterson je uvidio da je u teologiji njegova vremena dogmatski autoritet doveden u pitanje, a na njegovo se mjesto pokušava probiti autoritet savjesti i razuma. Tako se dogma pokušava istrgnuti iz religiozne sfere kojoj ona pripada, promatrajući je kroz optiku spoznajne teorije i logičkih silogizama ili polazeći od onoga što pojedinom teologu trenutno nalaže njegovo uvjerenje. Tome nasuprot naš autor tvrdi:

"Hir novovjekovne misli podrazumijeva konstrukciju teologije bez dogme. Takva je konstrukcija nepojmljiva. Ne zato što se čovjek - kao što se u otrcanoj apologetici često može čuti - nužno mora prikloniti dogmatskim izričajima kada želi nešto poduzeti. Kršćanska dogma nije koncesija na ljudsku sklonost dogmatiziranju. Naprotiv, dogma objavljuje rat svim ljudskim dogmatiziranjima. Teologija koja nije bitno određena dogmom tim je više utopija jer u njoj Kristova objava ne dolazi do izražaja." ${ }^{59}$

Peterson, kritizirajući tendenciju evangeličke teologije koja zanemaruje crkvenu dogmu, a sve više polazi od doxe profesora koji pokušavaju izgraditi teologiju na temelju svojih promišljanja i tvrdnji, želi ukazati na konstitutivno značenje koje dogma ima za teologiju. Svaki pokušaj izostavljanja dogme u teologiji sličan je pokušaju gradnje "babilonske kule" koja je osuđena na neuspjeh, a posljedica joj je brkanje jezika u teologiji općenito, što vodi nerazumijevanju i pomutnji. ${ }^{60}$ Takvo stanje teologije možda najbolje opisuje ova Petersonova usporedba:

"Kada razmišljam o današnjoj teologiji, čini mi se kao da se nalazim u učionici u kojoj je mnogo učenika koji glasno razgovaraju jedni s drugima, tako da se tek povremeno mogu razlikovati pojedine rečenice, nitko ne obraća pažnju na drugoga, a najglasniji je vrisak prihvaćen s naklonošću. No, kao što učenici zašute i razred se smiri kada učitelj stupi u učionicu, tako mora sva naša nada, čežnja i molitva stremiti k tome da poželi dolazak Logosa,

60 Usp. Erik Peterson, Über die gegenwärtige Lage der Theologie, 62-64. 
božanskog Pedagoga među nas, koji će varljivu buku svih onih dosjetki i subjektivnih uvjerenja utišati jednom svojom riječju."61

Drugim riječima, teologija mora postati svjesna da postoji snaga koja joj dolazi od Drugoga. Jasno je da ta snaga teologiji i Crkvi dolazi od obilja Kristova bogatstva, ali konkretan izraz te izvanjske, Kristove snage za teologe je crkvena dogma, tvrdi Peterson. Teologija bi zato trebala biti svjesna važnosti dogme koja je u svom religioznom smislu "kao ponorom odijeljena" od svih refleksija ovoga svijeta. Dogma ne počiva na autoritetu teologa pojedinca te ju se ne može smatrati nekom crkveno-političkom formulom koja bi nastala kao plod argumentacije nekog teologa ili teološke škole. Situacija je obratna - dogma, dakle, nije teološka refleksija niti nastaje kao njezina posljedica, nego teološka refleksija pretpostavlja dogmu. Iako su izražene u pojmovnoj formi, dogme nisu rezultat naravne konceptualizacije, jer nastaju u trenutku kad ih Crkva spoznaje te ne mogu napredovati u nekakav viši pojam.

"Dogmatika ne može biti osobna spekulacija nekog čovjeka izložena prema shemi wie ich es sehe [prema mome mišljenju, op. a.] upravo zato što dogma nije osobno uvjerenje pojedinca nego vjera Crkve. Dogmatika je zajedničko traganje mnogih generacija. Kao što dogma pripada Crkvi, tako joj pripada i dogmatsko djelo."62

\subsection{Religiozni smisao dogme}

Dogma se izvodi iz objave Logosa tako da ona u sebi nosi nešto od one konačnosti i jednoznačnosti Kristova govora. No činjenica da je Kristova objava i riječ konačna, ne znači ujedno da je svaka daljnja mogućnost konkretizacije te objave isključena. Njemački teolog Thomas Ervens primjećuje kako je Peterson uspio "očuvati i konačnost objave Logosa u Isusu Kristu, kao i povijesnost povijesti. Budući da se njihova autonomija prodorom objave ne ukida, potrebne su uvijek nove konkretizacije objave, drugim riječima, konkretizacije Dogme u dogmama. Peterson na taj način uspijeva povezati objavu u ondašnjem vremenu i eklezijalnu, odnosno vjersku situaciju danas, koje dogma, kao produžetak objave Logosa, povezuje". ${ }^{63}$

Možemo reći da je svaka nova dogma koju Crkva izriče snagom autoriteta predanog od Krista, prema Petersonu, produžetak i kon-

61 Isto, 58-66.

62 Erik Peterson, Thomas von Aquin, 11. Vorlesung. Theologie, Dogma, Kirche: Schlussbemerkungen, u: Isti, AS 9/1, 180-190., ovdje 189.

63 Thomas Ervens, Keine Theologie ohne Kirche, 87. 
kretizacija Kristova vječno aktualnoga govora. No same po sebi one ne bi značile ništa kada ne bi bile utemeljene u prvoj Dogmi "koja se, s početkom u onoj 'Iesous Kurios', pojavljuje u uvijek novim manifestacijama u crkvenom formiranju dogmi" . ${ }^{64}$ Prema tomu, dogme u cjelini prema Petersonu mogu biti shvaćene kao organizam u kojem je svaki ud upućen na drugoga te u toj povezanosti pojedine rasvjetljuju prvu Dogmu, dok prva Dogma daje smisao i vjerodostojnost ostalima. ${ }^{65}$

Bit je dogme da ona postoji kao nauk Crkve sazdan na temelju božanske objave. Ona kao izvor spoznaje može biti neposredna i izričito sadržana u Svetome pismu ili posredna i neizrečena tako da tek naknadno biva otkrivena i posredovana. Peterson polazi od ovog drugog načina dogmatskog rada Crkve, koji je puno više od pukoga teoretskog spoznavanja određenih istina. Ovdje se Crkva ističe kao kolektivni subjekt koji spoznaje polazeći od svoje egzistencijalne sfere na način da iznalazi dogme u životu mučenika i svetaca, u molitvi, mistici i kultu. ${ }^{66}$ Drugim riječima, dogma nastaje kao vjerska spoznaja Crkve koju ona izražava i definira kao svoj nauk.

Najbolji pokazatelj plodnosti i živosti teološkoga mišljenja prema Petersonu je skolastička teologija, koja je bitno određena dogmom i kojoj su dogmatska pitanja u središtu zanimanja. Međutim, hladni srednjovjekovni dogmatski izričaji zbog svoje su krutosti često (pogrešno) shvaćeni kao logički skladno uređen sustav koji bi istinu htio dohvatiti izvođenjem silogizama, odnosno Boga koji je Istina zatvoriti u granice apstraktnoga mišljenja. Drugim riječima, srednjovjekovna je dogmatika shvaćena kao adekvatan izričaj istine koja je u dogmi strogo zatvorena, u sebi završena i fiksirana. Zato bi se moglo pomisliti da se dogmatske izričaje u srednjovjekovnoj teologiji poimalo intelektualistički, tako što su predstavljali objektivan izričaj kojim se izražava neka vječna istina, pri čemu čovjekov odnos prema toj stvarnosti, njegovi moralni sudovi ili njegov duhovni život imaju tek sporedno značenje. ${ }^{67}$ No u pozadini takve percepcije zapravo je sljedeće:

64 Erik Peterson, Über die gegenwärtige Lage der Theologie, 61.

65 Usp. Isto, 61.

66 Erik Peterson, Der Begriff des Dogmas, 193.

67 Kako bi ukazao na bipolarnost razumijevanja dogme, s jedne strane ortodoksnoga, a s druge racionalističkoga, polazi od pijetističkoga gledišta koje smatra srednjim putem između ortodoksije i racionalizma, a ono se očituje u misli teologa Johanna Albrechta Bengela. Naime, Bengel ne odbacuje dogme Crkve niti ih racionalno ukida, ali naglašava da čin kojim shvaćamo dogmu nije čisto intelektualni čin, nego čin savjesti. Tako se, prema Bengelu, dogma može smatrati istinom, ali ona za njega nije ona konačna istina (die Wahrheit) utoliko što ona ne vodi $\mathrm{k}$ potpunom ostvarenju čovjeka. To se, prema Bengelu, očituje u tome 
"Ako se pojam dogme u ortodoksiji pričinja intelektualističkim, ipak je to u određenom smislu samo privid jer dogma kako ju izražava ortodoksija, svoje težište nema u čovjeku koji misli, nego u Bogu i njegovim objavljenim mislima. U njemu [pojmu dogme, op. a.] čudo božanske objave progovara nenarušeno od svega ljudskoga - odviše ljudskoga, ali i oslobođeno svih dvoznačnosti ljudske radinosti, ljudskoga idealizma i ljudskoga traganja za istinom. Dogma postaje izričaj božanske transcendencije."68

Iz toga proizlazi religiozni smisao dogme u kojemu je ona shvaćena kao očitovanje božanske istine, Božjega govora utemeljenog u njegovoj objavi. Zato takav dogmatski govor stoji u korelativnoj povezanosti Krista i Crkve pri čemu teologija zauzima posredničku ulogu $\mathrm{u}$ kojoj taj govor biva otjelovljen i konkretiziran. U takvom je govoru čovjeku prepuštena mogućnost odluke čime se uvažava čovjekova sloboda, računajući s njegovom odgovornošću. Dogma dakle omogućuje čovjekovu odluku za Krista ako se u njoj prepoznaje Kristov zahtjev poslušnosti spram njegova govora, poslušnosti koju samo Bog može zahtijevati. Tako shvaćena dogma ne predstavlja crkveni zahtjev poslušnosti vjere za samu Crkvu, već za Božji govor koji je dogmom posredovan.

\section{ZAKLJUČAK}

U iznesenim promišljanjima pokušali smo dati generalni uvid u ono što smo nagovijestili naslovom našeg rada, a to je Petersonovo poimanje teologije. Petersonovom kritikom Bultmannove i Barthove dijalektičke teologije uspjeli smo doći do nekoliko zaključaka. Prije svega, uvidjeli smo da polazište kršćanskoga govora o Bogu ne može biti čovjek i njegova egzistencija, već to mora biti Božja objava u Isusu Kristu. Utjelovljenje Božje riječi događaj je kojim Bog konkretno ulazi u ovaj svijet i zato govor o Bogu nije neka dijalektička mogućnost u kojoj nema konkretnih pitanja i odgovora, nije mitologija, nije neobvezujuća naracija o Bogu. Naprotiv, teologija izražava ozbiljnost Božje objave koja omogućuje konkretan govor o Bogu u formi dogme. Taj govor izriče Crkva, a dogma predstavlja zahtjev

što čovjek u svojoj savjesti još uvijek nema počinka. Riječ je zapravo o subjektivističkom shvaćanju dogme, gdje je čovjek u središtu. Peterson zaključuje da je Bengel zastupa etički koncept istine unutar kojega se dogma poima kao fiksacija trenutno postignutog stanja duše, savjesti, moralnog traganja za istinom, odnosno očitovanje čovjekove čežnje za Bogom. Usp. Erik Peterson, Dogma und Entwicklung, u: Isti, AS 9/1, 54-57., ovdje 54.

Isto, 54-55. 
krajnje određenosti, poslušnosti i vjere. Teologija je $u$ tom smislu konkretna argumentacija, produženje suda koji Crkva proglašava, a predstavlja svojevrsni produžetak Kristova govora. To teologija čini polazeći od autoriteta kojemu su korijen Kristove riječi: Ja vam kažem. Tako određenost teologije dogmom čuva vjeru da se ona ne uguši u pojedinačnoj egzistenciji i čistoj subjektivnosti, a odgovor te vjere je poslušnost spram Kristova govora izraženog u dogmi. ${ }^{69}$

Također smo pokazali da je pojam dogme u Petersonovoj misli nužno sagledavati u kontekstu ekleziologije. Iz toga proizlazi da je Petersonovu misao moguce razumijevati ako se ne izostavi pitanje crkvenosti teologije. Da bi teologija mogla nešto ozbiljno reći o Bogu, ona mora biti crkvena teologija, što pretpostavlja konkretan autoritet i dogmu. Sama dogma ne bi imala smisla kad ne bi postojao autoritet koji je može proglasiti, a taj se autoritet očituje u crkvenom autoritetu. Nedostatak tog autoriteta u protestantizmu teologiju je učinio izručenom mišljenju pojedinih teologa ili teoloških struja. S druge strane, Peterson je želio ukazati na to da se u dogmi potvrđuje trajna objektivnost Božje objave u povijesti kao i njezin autoritet spram svakoga ljudskog autoriteta. Međutim, u dogmi se očituje i ozbiljnost vjere $\mathrm{u}$ Isusa Krista. Vjera $\mathrm{u}$ dogmu, odnosno teologija određena dogmom predstavlja napuštanje egoistične vjere, odnosno, kao što ističe Peterson, napuštanje sheme wie ich es sehe (= kako ja to vidim). Nasuprot tomu, dogmatska je vjera prihvaćanje i ucjepljenje u vjeru Crkve koja svojim autoritetom utemeljenim u Kristovoj objavi, donosi objektivni sadržaj onoga u što se vjeruje.

Ako se naposljetku zapitamo u čemu se ogleda aktualnost Petersonove misli za teologiju današnjice, treba izdvojiti tri stvari.

Prvo, naglašavanjem središnjosti utjelovljenja Isusa Krista i dogme za teologiju, Peterson je podsjetio na novost Božje objave $u$ Kristu i nadnaravnost koja time određuje bit teologije. To nam se čini osobito važnim istaknuti u kontekstu krize današnje teologije: "Radi se o tomu da se kršćanska vjera više ne shvaća kao radikalna novost, kao novi Božji zahvat u povijest, kao novo Božje djelovanje spram ljudske naravi. Ljudska narav je danas postala glavno mjerilo i kriterij samoga kršćanstva. Sadržaji kršćanske vjere izgubili su svojstvo otajstva, a to znači da ih teologija doduše i dalje podučava, ali ona nisu više mjerilo i kriterij mišljenja. Štoviše, sva velika otajstva teologije pretvorila su se u neku vrstu okamina s kojima teologija više ne zna što bi učinila te pokazuje vrlo malen interes za njih. (...)

69 O odnosu dogme i egzistencije vidi Ivica Raguž, Uvod, u: Isti, Epimeteje, Panni, Đakovo, 2016., 9-13. 
Ili što je još gore, otajstva vjere, kojima se još moramo baviti, naturaliziramo: u otajstvima vjere odbacujemo ono što se čini suprotno našoj vlastitoj samovolji ili duhu vremena, ili pak dodajemo ono što nam se čini u skladu s našom samovoljom ili duhom vremena."70

Drugo, naš je autor pod pojmom "teološkoga staleža” uspio pokazati da teologija zahtijeva krajnju predanost i određenost Bogom i Crkvom. Teologija nije novinarstvo, puko "mišljenje", donošenje vlastitih stavova o vjeri, nego ona je znanost Crkve, koja se upravo zato ostvaruje nužno "u teološkom staležu”. Dakako, teološka misao postoji i izvan "teološkoga staleža”. To nije prijeporno za Petersona koji se sam nakon prelaska u Katoličku crkvu bavio teologijom. Peterson je naglašavanjem važnosti "teološkoga staleža" htio upozoriti na razliku između teološkog promišljanja i teologije u užem smislu riječi. Teološki može promišljati svatko, ali nastupati kao teolog, prema Petersonovu mišljenju, može samo onaj koji je unutar teološkoga staleža, odnosno onaj, kako bismo mi to danas rekli, koji ima "missio canonica" od strane Crkve. Tu treba spomenuti također i Kierkegaarda, pod čijim je utjecajem zasigurno i Peterson. Naime, i Kierkegaard, koji također teološki promišlja (i kako li tek teološki promišlja!), upravo zato što ne pripada "teološkom staležu" izbjegava sebe zvati teologom, vodeći računa upravo o tomu da on u svojim promišljanjima ne nastupa $u$ ime Crkve, već donosi svoja osobna promišljanja. Nadalje, Peterson govorom o "teološkom staležu" želi posvijestiti teolozima ozbiljnost njihova bavljenja teologijom, podsjeća ih na uzvišenost, ali i na opasnost velike zadaće koja im je dana od Crkve da se bave naukom Crkve, promišljaju ga i predstavljaju.

Treće, bavljenje teologijom pretpostavlja, s jedne strane, ono što bismo mogli nazvati znanstvenim duhom. Taj se znanstveni duh očekuje od svake znanosti pa tako i od teologije: rigoroznost mišljenja, dosljednost, sustavnost, objektivnost itd. S druge pak strane, teologija, za razliku od drugih znanosti, zahtijeva i više od znanstvenog duha, a to je duh vjere. Duh vjere podrazumijeva potpunu i cjelovitu obuzetost "objektom" istraživanja, a to je sam Bog. Zato za teologiju nije dovoljan samo "znanstveni duh", nego "duh vjere", a on se ostvaruje ponajprije u liturgiji, osobnoj molitvi, askezi, jednom riječju, u snažnom duhovnom življenju vlastite vjere. ${ }^{71}$ Gdje ne postoji takav "duh vjere"u teologiji, teologija može biti vrhunski znanstvena, a da pritom prestane biti teologija. Iz Petersonovih pro-

70 O uzrocima toga stanja, ali i poticajima za obnovu teologije: Ivica Raguž, Bijeda današnje teologije - smjerokazi za novu teologiju - dijalog i pomirenje u Hrvatskoj, u: Isti, Teološki fragmenti II., Panni, Đakovo, 2017., 9-29., ovdje 11., 13.

Više o tome: Isto, 15-17. 
mišljanja razvidno je da teologija dobiva svoju težinu i ozbiljnost ${ }^{72}$ te ostaje teologijom samo ako teolog polazi od duha vjere i razvija svoju misao unutar duha vjere.

Takva vjera nije, dakako, za njemačkog teologa nejasan skok $\mathrm{u}$ neodređeno, u nesigurno, nije ograničena samo spekulativnom spoznajom, nije čuvstvo, a nije ni izraz samo religijskoga iskustva i samosvijesti pojedinca. Naprotiv, vjera je ozbiljna odluka vjere, ali ne $u$ nesigurnost ljudske misli, nego se ona događa spram i naočigled Isusa Krista i vjere Crkve koja se izriče i ostvaruje također (jamačno, ne jedino na taj način) u njezinim dogmama, u kojima ozbiljnost i zahtjevnost Kristove objave dolazi do izražaja. Dogma, dakako, nije kraj mišljenja, nego početak, kriterij, mjera istinskoga teološkoga mišljenja. Dogma čuva time i izvornu znanstvenost same teologije (da se ona ne pretvori u filozofijsku teologiju, filozofiju, sociologiju ili u neke druge znanosti), koja može ostati znanstvenom, samo ako slijedi i ostaje vjerna svojim vlastitim principima, a to su upravo dogme.

\section{ERIK PETERSON'S UNDERSTANDING OF THEOLOGY}

\section{Summary}

The paper presents some aspects of thoughts of German theologian Erik Peterson about the essence, the preconditions and the role of theology. The first part starts with Peterson's critical attitude towards the two of his contemporaries - Rudolf Bultmann and his understanding of theology which originates from human existence and Karl Barth and his dialectical theology. With Peterson's criticism, we come to his own understanding of theology which specifically deals with the term of dogma. Thereby he endeavours to determine why this term takes a central place in his understanding of theology and which the consequences for theology itself are.

Keywords: Erik Peterson, theology, dogma, the Church, Karl Barth, Protestantism.

72 Više u takvoj vjeri vidi u: Ivica Raguž, Katolicizam, Panni, Đakovo, 2017., 11-18. O teologiji i vjeri vidi također Ivica Raguž, Neki vidovi teologije kao znanosti kod Tome Akvinskoga, Diacovensia, 24 (2016.) 1, 91-116. 